\title{
Dihydrotachysterol: a Calcium Active Steroid Not Dependent upon Kidney Metabolism
}

\author{
Harold E. Harrison and Helen C. Harrison \\ From the Departments of Pediatrics, Baltimore City Hospitals and Johns Hopkins \\ University School of Medicine, Baltimore, Maryland 21224
}

\begin{abstract}
A B S TRACT The activity of dihydrotachysterol and cholecalciferol was determined in nephrectomized or sham-operated vitamin D-depleted rats using in vitro transport of calcium and phosphate by everted intestinal preparations as the index of physiologic response. The activity of dihydrotachysterol was not reduced by absence of the kidneys whereas that of cholecalciferol was markedly inhibited so that at least a 10 -fold greater dose of the latter was necessary to produce an equivalent effect in the nephrectomized rat as in the control. Dihydrotachysterol is therefore equipotent with cholecalciferol in the anephric rat although much less active in the intact animal.
\end{abstract}

\section{INTRODUCTION}

Several molecular forms of vitamin $\mathrm{D}$ or related activated sterols derived from the UV irradiation of 7dehydrocholesterol (cholecalciferol and dihydrotachysterols) or of ergosterol (ergocalciferol and dihydrotachysterol 2 ) have both physiologic and pharmacologic actions. The former are determined by the healing of the skeletal lesions of rickets or by restoration to normal of the reduced serum calcium concentrations in vitamin D-depleted animals or man. These physiologic effects are closely correlated with the action of vitamin $D$ in increasing intestinal transport of calcium which is thought to be its primary action (1). The pharmacologic effect is measured by increase of serum calcium concentrations in the hypoparathyroid animal (2) or patient and is associated with both an increase of intestinal transport of calcium and altered bone metabolism leading to solubilization of bone mineral and maintenance of higher concentrations of calcium ion in

These studies were presented in part at the meeting of the Federation of American Societies for Experimental Biology, 10 April 1972.

Received for publication 28 February 1972 and in revised form 27 April 1972. body fluids. The pharmacologic effect requires amounts of vitamin D many fold that needed for physiologic action and merges into the toxic action of vitamin D which results in hypercalcemia and soft tissue calcification. There is an apparent dissociation between these physiologic and pharmacologic actions. Dihydrotachysterol 2 is much less potent than the calciferols in the vitamin $\mathrm{D}$-depleted animal but has actually greater pharmacologic potency than the calciferols in the hypoparathyroid subject (2). A possible clue to this discrepancy lies in the metabolic alterations which calciferol or dihydrotachysterol undergo in being transformed into physiologically active compounds.

Cholecalciferol is converted to a 25 -hydroxy derivative in the liver ( 3 ) and then is further metabolized by the kidney to 1,25-dihydroxycholecalciferol (4). The 1, 25-dihydroxy derivative is probably the active compound which is responsible for the physiologic effect of vita$\min$ D. Dihydrotachysterol is hydroxylated in the 25position (5) but there is no evidence of a 1,25-dihydroxy compound. If 25-hydroxydihydrotachysterol were not a suitable substrate for the kidney mitochondrial system which catalyzes the 1-hydroxylation of 25 hydroxycholecalciferol its relative lack of activity in the physiologic assay would be explained. Since this metabolic step occurs primarily and possibly exclusively in the kidney (4) this thesis could be tested by comparing the effect of nephrectomy on the activities of calciferol and dihydrotachysterol in vitamin D-depleted rats. A response to 25-hydroxydihydrotachysterol by the intestine of vitamin D-deficient anephric rats was shown by Hallick and DeLuca (5). The data in this paper extend these studies and show clearly that the presence of the kidneys markedly increases the potency of cholecalciferol but does not affect that of dihydrotachysterol.

\section{METHODS}

Weanling rats were depleted of vitamin D by a standard diet (6). The completeness of vitamin D depletion was checked 
by the reduction of serum calcium concentrations after 3 wk of diet. At this time, the rats were shifted to a low protein (8\% egg albumin), vitamin $D$-free diet which was also very low in potassium, sodium, and phosphate. On this diet vitamin $\mathrm{D}$-depleted rats tolerated nephrectomy, continued to feed, and continued in good physiologic condition for several days after nephrectomy making possible an accurate measure of vitamin $\mathrm{D}$ action on the intestinal transport of calcium and phosphate. After 3 days of this diet, animals were either bilaterally nephrectomized or subjected to sham operation as controls. 3-4 hr postoperatively the rats were given by stomach tube varying amounts of either crystalline cholecalciferol (ICN Nutritional Biochemicals Div., Cleveland, Ohio) or crystalline dihydrotachysterol 2 (PhilipsduPhar, Amsterdam) dissolved in propylene glycol. Dihydrotachysterol, was used because it is the compound which has been given to patients with renal insufficiency. Untreated animals were given only solvent. $42 \mathrm{hr}$ later, the animals were bled under pentobarbital anesthesia and the entire small intestine removed. The assay for vitamin $\mathrm{D}$ effect was the enhancement of calcium transport and of phosphate transport by everted intestinal loops in vitro as has been described (7). Calcium transport was measured in duodenal and ileal segments while phosphate transport was determined in mid-intestinal segments. The buffer for calcium transport studies contained sodium in a concentration of $\mathbf{5 0}$ $\mathrm{mEq} /$ liter since this has been found to give maximal calcium transport in both duodenum and ileum as well as in colon (8). The measure of solute transport was the final ratio of concentration of solute in serosal and mucosal fluids $(\mathrm{Cs} / \mathrm{Cm})$, the initial ratio being unity.

\section{RESULTS}

The data tabulated in Table I indicate the effects of cholecalciferol and dihydrotachysterol ${ }_{2}$ treatment on calcium and phosphate transport in sham-operated and nephrectomized rats. The calcium transport in duodenum and ileum and the phosphate transport in mid-intestine roughly parallel each other and there is no evidence of a major differential effect of type of steroid or of kidney removal on intestinal site or on the ion transported. $2.5 \mu \mathrm{g}$ of cholecalciferol produces a near maximal enhancement of calcium and phosphate transport in intestine from sham-operated animals whereas dihydrotachysterols has very little effect at this dose. This amount of cholecalciferol has only a slight action on calcium transport and no effect on phosphate transport, however, in intestine from nephrectomized rats. With increasing dosage of both compounds it becomes apparent that the absence of kidney tissue does not impair dihydrotachysterol effect whereas cholecalciferol action is markedly inhibited so that in the nephrectomized rat dihydrotachysterol is as, or more potent than comparable doses of cholecalciferol.

In these experiments the uremic state per se apparently has little effect on the intestinal transport systems apart from metabolic conversion of vitamin D since, in the untreated vitamin D-depleted rat, nephrectomy causes no significant reduction in the already low level of in vitro transport of calcium in the duo-
TABLE I

Comparison of Effects of Cholecalciferol (CC) and Dihydrotachysterol (DHT) on In Vitro Calcium and Phosphate Transport by Everted Intestinal Loops of ShamOperated and Nephrectomized Vitamin D-Depleted Rats

\begin{tabular}{|c|c|c|c|c|c|}
\hline \multirow[b]{2}{*}{ Steroid } & \multicolumn{2}{|c|}{ DHT } & \multicolumn{3}{|c|}{$\mathrm{CC}$} \\
\hline & Sham & Nephrectomized & Sham & & ephrectomized \\
\hline$\mu g$ & & & & & \\
\hline \multicolumn{6}{|c|}{ Calcium transport-duodenum $(\mathrm{Cs} / \mathrm{Cm})$} \\
\hline 0 & $\begin{array}{c}2.02 \pm 0.16 \\
(13) \\
*\end{array}$ & $\begin{array}{c}1.87 \pm 0.11 \\
(11) \\
* *\end{array}$ & $\begin{array}{c}2.02 \pm 0.16 \\
(13) \\
* *\end{array}$ & & $\begin{array}{c}1.87 \pm 0.11 \\
(11) \\
*\end{array}$ \\
\hline 2.5 & $\begin{array}{c}2.86 \pm 0.18 \\
(6)\end{array}$ & $\begin{array}{c}3.57 \pm 0.23 \\
(7)\end{array}$ & $\begin{array}{c}8.57 \pm 0.32 \\
(7)\end{array}$ & $* *$ & $\begin{array}{c}3.04 \pm 0.34 \\
(7)\end{array}$ \\
\hline 10 & $\begin{array}{c}3.00 \pm 0.34 \\
(6)\end{array}$ & $\begin{array}{c}4.29 \pm 0.69 \\
(7)\end{array}$ & $\begin{array}{c}9.29 \pm 1.26 \\
(9)\end{array}$ & $* *$ & $\begin{array}{c}3.99 \pm 0.82 \\
(7)\end{array}$ \\
\hline 25 & $\begin{array}{c}7.49 \pm 1.30 \\
(6)\end{array}$ & $\begin{array}{c}11.67 \pm 2.01 \\
(6)\end{array}$ & $11.0 \underset{(8)}{ \pm 0.99}$ & $* *$ & $\begin{array}{c}6.20 \pm 0.89 \\
(7)\end{array}$ \\
\hline \multicolumn{6}{|c|}{ Calcium transport-ileum ( $\mathrm{Cs} / \mathrm{Cm})$} \\
\hline $\mathbf{0}$ & $\begin{array}{c}0.89 \pm 0.04 \\
(13)\end{array}$ & $\begin{array}{c}* 0.71 \pm 0.02 \\
(12) \\
* *\end{array}$ & $\begin{array}{c}0.89 \pm 0.04 \\
(13) \\
* *\end{array}$ & * & $\begin{array}{c}0.71 \pm 0.02 \\
(12) \\
* *\end{array}$ \\
\hline 2.5 & $\begin{array}{c}1.04 \pm 0.07 \\
(7)\end{array}$ & $\begin{array}{c}1.48 \pm 0.19 \\
(7)\end{array}$ & $\begin{array}{c}2.69 \pm 0.27 \\
(5)\end{array}$ & $* *$ & $\begin{array}{c}0.97 \pm 0.04 \\
(7)\end{array}$ \\
\hline 10 & $\begin{array}{c}1.55 \pm 0.27 \\
(6)\end{array}$ & $\begin{array}{c}1.56 \pm 0.16 \\
(8)\end{array}$ & $\begin{array}{c}3.17 \pm 0.33 \\
(9)\end{array}$ & $* *$ & $\begin{array}{c}0.97 \pm 0.08 \\
(8)\end{array}$ \\
\hline 25 & $\begin{array}{c}2.11 \pm 0.18 \\
(6)\end{array}$ & $\begin{array}{c}2.51 \pm 0.20 \\
(6)\end{array}$ & $\begin{array}{c}2.89 \pm 0.34 \\
(6)\end{array}$ & $* *$ & $\begin{array}{c}1.78 \pm 0.20 \\
(7)\end{array}$ \\
\hline \multicolumn{6}{|c|}{ Phosphate transport $(\mathrm{Cs} / \mathrm{Cm})$} \\
\hline $\mathbf{0}$ & $\begin{array}{c}1.54 \pm 0.07 \\
(13)\end{array}$ & $\begin{array}{c}1.62 \pm 0.14 \\
(12)\end{array}$ & $\begin{array}{c}1.54 \pm 0.07 \\
(13) \\
* *\end{array}$ & & $\begin{array}{c}1.62 \pm 0.14 \\
(12)\end{array}$ \\
\hline 2.5 & $\begin{array}{c}1.68 \pm 0.08 \\
(6)\end{array}$ & $\begin{array}{c}1.78 \pm 0.15 \\
(7)\end{array}$ & $\begin{array}{c}2.69 \pm 0.19 \\
(7)\end{array}$ & $* *$ & $\begin{array}{c}1.55 \pm 0.06 \\
(7)\end{array}$ \\
\hline 10 & $\begin{array}{c}2.02 \pm 0.16 \\
(6)\end{array}$ & $\begin{array}{c}2.03 \pm 0.09 \\
(8)\end{array}$ & $\begin{array}{c}3.45 \pm 0.91 \\
(9)\end{array}$ & $* *$ & $\begin{array}{c}1.61 \pm 0.14 \\
(7)\end{array}$ \\
\hline 25 & $\begin{array}{c}2.61 \pm 0.35 \\
(6)\end{array}$ & $\begin{array}{c}2.94 \pm 0.38 \\
(6)\end{array}$ & $\begin{array}{c}3.20 \pm 0.29 \\
(8)\end{array}$ & $* *$ & $\begin{array}{c}2.01 \pm 0.15 \\
(7)\end{array}$ \\
\hline
\end{tabular}

Values are means \pm SEM. No. of animals in group in parentheses. * Difference between values statistically significant $P<0.05$. ** Difference between values highly significant $P<0.01$.

denum although there is a decrease in ileal transport. When $2.5 \mu \mathrm{g}$ of cholecalciferol are given $18 \mathrm{hr}$ before nephrectomy and intestinal transport determined $42 \mathrm{hr}$ postnephrectomy $\mathrm{Cs} / \mathrm{Cm}$ ratios for calcium transport in duodenum and ileum are $7.86 \pm 0.37$ and $2.26 \pm 0.23$ and that for phosphate $2.49 \pm 0.28$. The effect of uremia is thus not sufficient to inhibit cholecalciferol effect once conversion to the active metabolite by the kidney has occurred. Sham-operated rats pretreated with 2.5 $\mu \mathrm{g}$ of cholecalciferol do show a greater increment of transport than do the nephrectomized rats but this is not necessarily evidence of an inhibitory effect of uremia and may indicate that conversion of cholecalciferol to 1,25-dihydroxycholecalciferol continues beyond the 18 $\mathrm{hr}$ interval between administration and operation so that the sham-operated rats have a greater response 
due to continued formation and therefore greater concentration of the active metabolite.

In Table II are summarized serum calcium, phosphate, and citrate concentrations of the animals from which the data of Table I were obtained. When the vitamin $\mathrm{D}$-depleted rats are changed from the original diet containing $0.6 \% \mathrm{Ca}$ and $0.5 \% \mathrm{P}$ to the low protein, phosphate-free diet without change in calcium intake the serum calcium rises to normal as the serum inorganic phosphate drops. The low phosphate intake prevents any marked increase of serum phosphate after nephrectomy. In the anephric rats there is a marked rise in concentrations of serum citrate and of calcium which has been observed by others (9). This probably is the result of the removal of the citrate metabolizing tissue of the kidney. The rise of citrate and of calcium concentrations is greater in rats receiving 10 and $25 \mu \mathrm{g}$ of dihydrotachysterol than in those given comparable amounts of cholecalciferol. This may indicate relatively greater mobilization of citrate and of calcium from

TABLE II

Concentrations of Calcium, Phosphate, and Citrate in Serum of Nephrectomized or Sham-Operated Vitamin D-Depleted Rats Given Varying Doses of Cholecalciferol $(C C)$ or Dihydrotachysterol (DHT) $4 \mathrm{hr}$ after Operation. Blood Taken 42 hr after Operation

\begin{tabular}{|c|c|c|c|c|}
\hline \multirow[b]{2}{*}{ Steroid } & \multicolumn{2}{|c|}{ DHT } & \multicolumn{2}{|c|}{$\mathrm{CC}$} \\
\hline & Sham & Nephrectomized & Sham & Nephrectomized \\
\hline$\mu g$ & \multicolumn{4}{|c|}{ Calcium, $m g / 100 m l$} \\
\hline $\mathbf{0}$ & $\underset{(12)}{10.08 \pm 0.06}$ & $\begin{array}{c}12.93 \pm 0.30 \\
(12)\end{array}$ & $\underset{(10)}{10.08} \pm 0.06$ & $\begin{array}{c}12.93 \pm 0.30 \\
(12)\end{array}$ \\
\hline 2.5 & $\begin{array}{c}10.13 \pm 0.11 \\
(7)\end{array}$ & $\begin{array}{c}13.97 \pm 0.30 \\
(7)\end{array}$ & $\begin{array}{c}11.90 \pm 0.19 \\
(7)\end{array}$ & $\begin{array}{c}13.03 \pm 0.31 \\
(7)\end{array}$ \\
\hline 10 & $\begin{array}{c}10.37 \pm 0.15 \\
(6)\end{array}$ & $\begin{array}{c}13.93 \pm 0.43 \\
(8)\end{array}$ & $\begin{array}{c}12.29 \pm 0.24 \\
\text { (9) }\end{array}$ & $\begin{array}{c}12.89 \pm 0.37 \\
(8)\end{array}$ \\
\hline 25 & $\begin{array}{c}11.65 \pm 0.27 \\
(6)\end{array}$ & $\begin{array}{c}17.20 \pm 0.94 \\
(6)\end{array}$ & $\begin{array}{c}12.84 \pm 0.21 \\
(5)\end{array}$ & $\begin{array}{c}13.84 \pm 0.71 \\
(7)\end{array}$ \\
\hline \multicolumn{5}{|c|}{ Citrate, $m g / 100 m l$} \\
\hline $\mathbf{0}$ & $\begin{array}{c}4.86 \pm 0.33 \\
\text { (6) }\end{array}$ & $\begin{array}{c}18.03 \pm 1.96 \\
(6)\end{array}$ & $\begin{array}{c}4.86 \pm 0.33 \\
\text { (6) }\end{array}$ & $\begin{array}{c}18.03 \pm 1.96 \\
(6)\end{array}$ \\
\hline 2.5 & $\begin{array}{l}4.51 \pm 0.31 \\
(5)\end{array}$ & $\begin{array}{c}14.82 \pm 3.02 \\
(7)\end{array}$ & - & $\begin{array}{c}15.54 \pm 2.22 \\
(4)\end{array}$ \\
\hline 10 & $\begin{array}{l}5.63 \pm 0.52 \\
\quad(4)\end{array}$ & $\begin{array}{c}22.33 \pm 3.82 \\
(6)\end{array}$ & $\begin{array}{c}7.46 \pm 0.26 \\
(8)\end{array}$ & $\begin{array}{c}12.03 \pm 1.13 \\
(7)\end{array}$ \\
\hline 25 & $\begin{array}{c}5.33 \pm 0.13 \\
(5)\end{array}$ & $\begin{array}{c}31.50 \pm 4.41 \\
(5)\end{array}$ & - & $\begin{array}{c}21.33 \pm 1.75 \\
(3)\end{array}$ \\
\hline \multicolumn{5}{|c|}{ Phosphate, $m g / 100 m l$} \\
\hline $\mathbf{0}$ & $\begin{array}{c}1.20 \pm 0.10 \\
\text { (11) }\end{array}$ & $\begin{array}{l}2.32 \pm 0.36 \\
\quad(12)\end{array}$ & $\begin{array}{c}1.20 \pm 0.10 \\
\text { (11) }\end{array}$ & $\begin{array}{l}2.32 \pm 0.36 \\
\quad(12)\end{array}$ \\
\hline 2.5 & $\begin{array}{c}1.54 \pm 0.17 \\
(7)\end{array}$ & $\begin{array}{l}2.12 \pm 0.21 \\
\quad(7)\end{array}$ & $\begin{array}{l}2.52 \pm 0.29 \\
\text { (6) }\end{array}$ & $\begin{array}{l}2.27 \pm 0.23 \\
\quad(7)\end{array}$ \\
\hline 10 & $\begin{array}{c}1.13 \pm 0.15 \\
\text { (6) }\end{array}$ & $\begin{array}{c}2.74 \pm 0.17 \\
(8)\end{array}$ & $\begin{array}{l}2.29 \pm 0.24 \\
\text { (9) }\end{array}$ & $\begin{array}{c}2.06 \pm 0.17 \\
(8)\end{array}$ \\
\hline 25 & $\begin{array}{l}1.71 \pm 0.16 \\
(6)\end{array}$ & $\begin{array}{c}2.98 \pm 0.40 \\
(6)\end{array}$ & $\begin{array}{c}3.00 \pm 0.35 \\
\quad(5)\end{array}$ & $\begin{array}{l}2.25 \pm 0.21 \\
\quad(4)\end{array}$ \\
\hline
\end{tabular}

Values are means \pm SEM. No. of animals in group in parentheses. bone by this steroid in the nephrectomized animal. A greater physiologic effect of dihydrotachysterol than of cholecalciferol in the nephrectomized rat is also suggested by results of the calcium transport studies (Table I).

\section{DISCUSSION}

The data show that a major difference between cholecalciferol and dihydrotachysterol is activation of the former by the kidney presumably by transformation to a highly active compound, 1,25-dihydroxycholecalciferol, whereas dihydrotachysterol activity is not increased by kidney. Under the conditions of this study, the effects of uremia on the calcium and phosphate transport systems of the intestine are not a major factor, and there is certainly no reduction of dihydrotachysterol effect in the anephric rat.

Inasmuch as dihydrotachysterol in large doses does enhance calcium and phosphate transport by intestine of vitamin D-deficient rats and cholecalciferol in similar doses also does the same in preparations from nephrectomized rats the kidney is not completely essential for vitamin $\mathrm{D}$ effect even though it metabolizes calciferol to a much more active compound. This may mean that derivatives other than the 1,25-dihydroxy compounds have an action on intestinal transport of calcium. Since both calciferol and dihydrotachysterol are metabolized to 25-hydroxy compounds these may be physiologically active but with a much lower potency than the 1,25-dihydroxy calciferol, or alternately other dihydroxy compounds such as the 21,25 dihydroxycholecalciferol isolated by Suda et al. (10) may be formed in the absence of the kidney and be somewhat active in the intestinal assay. It is also possible that hydroxylation at the 1 carbon could occur in tissues other than the kidney but at a much lower rate. If so, such extrarenal metabolism must be as great or greater for dihydrotachysterol than for cholecalciferol and this seems unlikely. In either instance, 25-hydroxydihydrotachysterol is not metabolized to a more active compound by the kidney presumably because it is not a suitable substrate for the kidney 1-hydroxylation system. This can explain the much lower potency of dihydrotachysterol than of calciferol in the vitamin D-depleted animal. Since at pharmacologic doses dihydrotachysterol is more potent than calciferol in the hypoparathyroid subject (2), dihydrotachysterol or its derivative is evidently more active than the calciferol metabolite with respect to solubilization of bone mineral in the absence of parathyroid hormone.

In patients with renal disease, calcium malabsorption refractory to ordinary amounts of vitamin $D$ is a well recognized problem (11). Lack of the formation of 1,25-dihydroxycalciferol due to severe reduction of ac- 
tive renal metabolic tissue has been postulated to be the mechanism. Under these conditions dihydrotachysterol may be the preferable steroid for treatment rather than larger doses of calciferol since the amount of dihydrotachysterol required will not vary with changes in amount of functioning kidney tissue. The dosage of dihydrotachysterol should be more uniform, therefore, and not greatly different from that necessary to produce a physiologic action on calcium absorption in the subject with intact kidneys. Liu and Chu (12) and Kaye, Chatterjee, Cohen, and Sagar (13) have demonstrated that dihydrotachysterol does increase calcium absorption by the patient with renal insufficiency and suppresses secondary hyperparathyroidism more effectively than equivalent doses of calciferol.

\section{ACKNOWLEDGMENTS}

We appreciate the skillful technical assistance of Mrs. Evelyn Bull.

This investigation was supported by U. S. Public Health Service, National Institutes of Health Grant AM-00668.

\section{REFERENCES}

1. DeLuca, H. F. 1967. Mechanism of action and metabolic fate of vitamin D. Vitam. Horm. 28: 315.

2. Harrison, H. E., H. C. Harrison, and F. Lifshitz. 1968. Interrelation of vitamin $\mathrm{D}$ and parathyroid hormone. The responses of vitamin $\mathrm{D}$ depleted and of thyroparathyroidectomized rats to ergocalciferol and dihydrotachysterol. In Parathyroid Hormone and Thyrocalcitonin (Calcitonin). R. V. Talmage and L. F. Belanger, editors. Excerpta Medica Foundation, Amsterdam. 455.

3. Blunt, J. W., H. F. DeLuca, and H. R. Schnoes. 1968. 25-hydroxycholecalciferol. A biologically active metabolite of vitamin $\mathrm{D}_{3}$. Biochemistry. 7: 3317.

4. Fraser, D. R., and E. Kodicek. 1970. Unique biosynthesis by kidney of a biologically active vitamin $D$ metabolite. Nature (Lond.) 228: 764.

5. Hallick, R. B., and H. F. DeLuca. 1972. Metabolites of dihydrotachysterol ${ }_{3}$ in target tissues. J. Biol. Chem. $247: 91$.

6. Harrison, H. C., H. E. Harrison, and E. A. Park. 1958. Vitamin D and citrate metabolism. Effect of vita$\min \mathrm{D}$ in rats fed diets adequate in both calcium and phosphorus. Am. J. Physiol. 192: 432.

7. Harrison, H. E., and H. C. Harrison. 1960. Transfer of $\mathrm{Ca}^{45}$ across the intestinal wall in vitro in relation to the action of vitamin D and cortisol. Am. J. Physiol. $199: 265$.

8. Harrison, H. C., and H. E. Harrison. 1969. Calcium transport by rat colon in vitro. Am. J. Physiol. 217: 121.

9. Freeman, S., and T. S. Chang. 1950. Role of the kidney and of citric acid in production of a transient hypercalcemia following nephrectomy. Am. J. Physiol. 160: 355.

10. Suda, T., H. F. DeLuca, H. K. Schnoes, G. Ponchon, V. Tanaka, and M. F. Holick. 1970. 21,25-dihydroxycholecalciferol. A metabolite of vitamin $\mathrm{D}_{3}$ preferentially active on bone. Biochemistry. 9: 2917.

11. Lumb, G. A., E. B. Mawer, and S. W. Stanbury. 1971. The apparent vitamin D resistance of chronic renal failure. A study of the physiology of vitamin D in man. Am. J. Med. 50: 421.

12. Liu, S. H.. and H. I. Chu. 1943. Studies of calcium and phosphorus metabolism with special reference to pathogenesis and effects of dihydrotachysterol (A. T. 10) and iron. Medicine. 22: 103.

13. Kaye, M., M. B. Chatterjee, G. F. Cohen, and S. Sagar. 1970. Arrest of hyperparathyroid bone disease with dihydrotachysterol in patients undergoing chronic dialysis. Ann. Intern. Med. 73: 225. 